\title{
Grassroots action for renewable energy: how did Ontario succeed in the implementation of a feed-in tariff system?
}

Kensuke Nishimura

\begin{abstract}
Background: This article examines the policymaking process of Ontario's Green Energy Act (GEA) which enabled the introduction of the first comprehensive feed-in tariff (FIT) in North America. The FIT, which is a payback system for renewable energy (RE) producers, was implemented in order to make Ontario a Green Leader in North America. This article analyzes this process through a consideration of the role played by grassroots action.

Methods: The Green Energy Act Alliance (GEAA) succeeded in the implementation of the GEA. Using Lober's collaborative window, this article explores factors that led to the realization of the FIT. The conclusion will show that the GEAA succeeded in opening the collaborative window, even though the model's prerequisites were not completely fulfilled, namely there was a lack of public awareness.

Results: The diffusion of innovation theory helps us to understand this, with regard to the GEAA's strategy. The policymakers had recognized the importance of RE but had not yet been motivated to develop RE generating capacity in the region. The GEAA changed their opinion by showing the success of the FIT in Europe in boosting the economy.

Conclusions: After the European study tour, the Minister of Energy, George Smitherman, as one of the important policymakers, started to support the GEA, and this was the key factor leading to the introduction of the FIT, despite a lack of public awareness.
\end{abstract}

Keywords: Ontario, Feed-in tariff, Green Energy Act, Grassroots action, Multiple streams theory, Collaborative window, Diffusion of innovation

\section{Background}

The GEA: the fundamental change generated by a grassroots action

The Green Energy Act (GEA), enacted in 2009 by the Ontario legislature in order to expand renewable energy (RE) generating capacity in the region, has had a major impact on Ontario's energy policy. This act was the first in North America's states/provinces to adopt a feed-in tariff (FIT) system, under which RE producers are repaid their electricity production costs. After its implementation, the program received applications for 15,000 MW of RE supply within the first year, equivalent to approximately $43 \%$ of Ontario's total electricity generation

Correspondence: k.nishimura@fu-berlin.de

Environmental Policy Research Centre, Free University of Berlin, Ihnestrasse 22, Berlin, D-14195, Germany

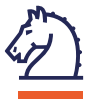

capacity [1]. For this reason, the Ontario FIT has recently received praise from scholars and politicians for being one of the most successful local climate policies.

An increasing number of studies analyze the program in detail, for example, Yatchew [1] and Winfield et al. [2]. The main findings of these studies are that the GEA, unlike previous measures supporting RE, offered the potential to fundamentally change Ontario's energy policy and that this contributed to the improvement of local and weak actors' income through special support schemes for communities and aborigines willing to invest in RE. However, there are still only a relatively small number of studies that discuss the policymaking process of the GEA. It has therefore yet to be explained why the first FIT in North America was realized in Ontario in 2009. The formation of the GEA policy was 
driven by grassroots action in which various actors, including nongovernmental organizations (NGOs) and politicians, participated. This article offers an understanding of the GEA's policymaking process from the perspective of the role played by this grassroots activity.

There have been many recent important studies that seek to explain Ontario's energy policy. Harper [3], for instance, analyzed articles about RE that were published in local newspapers between 2003 and 2007 and concluded that the public awareness of RE in Ontario at this time was relatively low. Out of all these studies, this article especially draws upon the work of Rowlands [4]. Rowlands analyzed the policymaking process of Ontario's energy policy and identified two significant shifts within the Ontario government's support for RE. The first shift was the implementation of a Renewable Portfolio Standard (RPS) to support RE despite the existence of a liberalized electricity market in Ontario. The second shift was the replacement of the Portfolio Standard with the Renewable Energy Standard Offer Program (RESOP). However, both policy measures did not increase the RE generating capacity as much as was expected; therefore, the GEA became a key alternative to the RESOP in enhancing RE development in the region. This article explores why grassroots action led to the successful implementation of the FIT, a policy which has led to greater changes in Ontario's energy policy than the RESOP. In addition, it will look at what strategies were used to overcome the unsatisfactory results of previous RE support measures.

\section{Renewable energy and support schemes}

$\mathrm{RE}$ is an energy source which can be regenerated in the natural energy cycle. The importance of RE has increased in the last two decades, because it does not contribute to climate change. The Ontario government defined RE as biogas, renewable biomass, solar (photovoltaic), small hydro, and on- and offshore wind power, all of which were supported by the FIT framework. The development of RE requires governmental support due to political and financial barriers it faces [5]. The lack of financial support for RE, compared to the subsidies provided for fossil fuel and nuclear power, and the limited access to the market for independent electricity producers are criticized by scholars and practitioners. To overcome these barriers, governments should provide stable financial and/or political support to ensure the introduction of renewable sources.

The RPS is the policy measure which has been implemented in most North America's states/provinces. The RPS is a quota system which sets percentage targets for the amount of RE to be included in the power generation mix of a certain locale [5]. Electricity distributers must ensure that a certain percentage of the electricity sold is generated by RE. The RPS is often combined with an emissions trading system to provide relief for those who fail to achieve the required rate.

In contrast, the FIT is a pricing law, under which producers of RE are paid a set rate for their electricity, usually differentiated according to the technology used and the size of the installation. The payback rate and period should be scientifically calculated to ensure that a profitable operation is guaranteed. It is important that the additional costs of this scheme are paid by suppliers in proportion to their sales volume and are passed down to power consumers by way of a premium on the enduser price. The FIT places the obligation on electricity distributors to buy the electricity generated by RE sources and to open up grid access for independent RE producers [5].

Existing empirical studies suggest that worldwide there is no better environmental policy than a well-designed and fully complemented FIT for triggering rapid, lowcost RE development [5]. As of 2010, the FIT has been implemented in 50 countries and 25 states/provinces [6]. These 25 states/provinces are mostly located in India, Canada, Australia, and the United States. The RESOP was a similar program to the FIT, but the size of RE facilities supported by the RESOP was limited to $10 \mathrm{MW}$.

\section{Ontario's RE support measures}

Ontario accounts for $37.8 \%$ of Canada's economy based on its GDP [7]. It is a 'part of the North American manufacturing heartland,' which relies heavily on fossil fuels [8] and, over the last 10 years, has been the Canadian province with the highest levels of energy consumption. Ontario's local government was, therefore, not enthusiastic about promoting RE.

Ontario's peak energy demand in summer 2011 was estimated on the basis of normal seasonal weather conditions to be 23,539 MW [9]. Ontario's 2011 installed electricity generation capacity totaled 34,882 MW [10]. Nuclear accounts for $33 \%$ of total generating capacity, followed by gas with a $27 \%$ share. Twenty-three percent is generated by hydropower (mainly large hydropower plants, which are not supported by the FIT) and 13\% is from coal. Wind power provides $4 \%$, and $0.3 \%$ is from other sources such as biomass.

In 2009, Ontario emitted $165 \mathrm{Mt}$ of greenhouse gas (GHG), corresponding to 23.9\% of Canada's 2009 total GHG emissions [11]. Ontario has decreased its GHG emissions by $7 \%$ since 1990 . However, this achievement is still far from the 15\% GHG emission reduction target by 2020 compared to that of 1990 that Ontario has proclaimed [12].

Ontario had used two different RE support schemes before introducing the GEA. Firstly, the Ontario 
Table 1 RPS and RESOP of Ontario

\begin{tabular}{llcl}
\hline RE support schemes & $\begin{array}{c}\text { Year } \\
\text { issued }\end{array}$ & Note \\
\hline RPS $\quad \begin{array}{l}5 \%, 10 \% \text {, and 1\% of generating capacity from renewables by 2007, 2010, and } \\
2004, \text { respectively }\end{array}$ & 2004 & $\begin{array}{l}\text { In response to phase-out from coal-fired power } \\
\text { plants by 2007 }\end{array}$ \\
RESOP Guaranteed price for 20 years \\
$\begin{array}{l}11 \mathrm{c} / \mathrm{kWh} \text { for wind, water, biomass; } 42 \mathrm{c} / \mathrm{kWh} \text { for photovoltaic (PV); available to } \\
\text { projects under 10 MW }\end{array}$ & $2006 \begin{array}{l}\text { In response to phase-out from coal-fired power } \\
\text { plants by 2007 }\end{array}$ \\
\hline Adapted from GEAA's website [13].
\end{tabular}

government initiated the RPS in 2004 and afterwards replaced it with the RESOP in 2006. The RESOP was similar to the FIT in that RE producers were paid back for their production costs (see Table 1).

Corresponding to its aim of encouraging local small energy producers to invest in RE, the RESOP included a limitation on the size of generating capacity covered by the program which became a barrier for the growth of potential RE producers.

The Green Energy and GEA launched the comprehensive FIT in order to abolish the RESOP's limitations on the size of generating capacity. Ontario's FIT was designed to transfer European best practices, with the greatest influence on the GEA coming from the German FIT [14]. The characteristics of the GEA were as follows: (1) the rate of the payback price depended on the size and source of RE; (2) the duration of the contract was 20 years; (3) there were two different types of the program depending on the size of RE power plants installed; and (4) special measures for aboriginal and community-based projects were available.

With regard to the last two points, the GEA introduced the FIT and the microFIT program, which was available for projects not exceeding $10 \mathrm{~kW}$ of capacity. The main aims of the GEA were to both increase the installed RE energy capacity to ensure adequate generation and to reduce GHG emissions at the same time, to provide a simpler method to procure RE, to create new green industries through investment and job creation, and to provide incentives for investment in renewable technologies.
The fixed price for photovoltaic, small hydro, and on and offshore wind power is displayed in Table 2. The Ontario government stressed that the GEA would create 50,000 new job opportunities in the region. The GEA was ratified on 14 May 2009 and the FIT was initiated in April 2010. As the FIT guaranteed RE producers to be paid back according to their size and renewable sources they use, the FIT was supposed to boost the regional economy by creating a new technology market and providing better air quality.

\section{Policymaking process, policy window, and policy entrepreneur}

According to Kingdon [16], the lifecycle of a policy can be divided into five stages: agenda setting, alternative selection, political decision, policy implementation, and policy evaluation. This article focuses on policymaking, which corresponds to the first three stages. The 'garbage can model' [17] is a popular method used to analyze a pre-decision process. The garbage can model stresses that decision makers are often not rational when making a political decision. Kingdon [16] further developed the garbage can model into a policy window theory, also known as the 'multiple stream model' (MS model). The MS model stresses that a policy window often opens accidentally and only for a short period. The MS model is useful in understanding why one alternative was chosen and others not. This article employs the MS model to explore the background of why the FIT became an attractive policy tool for policymakers in Ontario at that time. Lober [18] expanded the MS model to analyze the

Table 2 Selected fixed price for the GEA

\begin{tabular}{lcc}
\hline Technology & Capacity range & Proposed price (c/kWh) \\
\hline Rooftop or ground-mounted solar PV & $\leqq 10 \mathrm{~kW}$ & 80.2 \\
\hline Rooftop solar PV & $>10 \mathrm{~kW} \leqq 250 \mathrm{~kW}$ & 71.3 \\
\hline Rooftop solar PV & $>250 \mathrm{~kW} \leqq 500 \mathrm{~kW}$ & 63.5 \\
\hline Rooftop solar PV & $>500 \mathrm{~kW}$ & 53.9 \\
\hline Ground-mounted solar PV & $>10 \mathrm{~kW} \leqq 10 \mathrm{MW}$ & 44.3 \\
\hline Onshore wind & Any size & 13.5 \\
\hline Offshore wind & Any size & 19 \\
\hline Water power & $\leqq 10 \mathrm{MW}$ & 13.1 (40 years) \\
\hline
\end{tabular}

Adapted from OPA [15]. 
motivations of actors collaborating in policy formation. This article explores the initial stage of the collaboration between grassroots actors and policymakers, regarding the question of how grassroots actors, who are outside of the policy arena, can reach important policymakers to make them act in support of their goals. To address this question, this paper introduces Roger's 'diffusion of innovation theory' [19]. The diffusion of innovation theory is useful in its analysis of the influence of policy entrepreneurs outside of a policy arena on policymakers, while the MS model is suited better to explain change within the policy arena. Inspired by these two theories, this article examines the Ontario FIT case to explore at what point in time a policy window opens to allow a grassroots action to influence a policy change and whether the contingency of the policy window opening can to some degree be influenced by grassroots action.

\section{Methods}

This article examines a case study in which grassroots action in Ontario successfully led to the implementation of the FIT. This case is interesting due to the speed of the policy change. Kingdon's MS model is especially helpful in explaining the factors enabling short-term change in political issues. The MS model, based on the garbage can model, focuses on the agenda-setting and decision-making stages in which the policy change occurred and explains who opened the policy window and when this occurred. The MS model tries to answer four questions: (1) how is a problem acknowledged and defined, (2) how is a policy measure generated, (3) how does a political event emerge, related to the problem and the measure, and finally (4) how is the political event connected to the problem and the measure at the appropriate time? Kingdon identifies three streams flowing through the system: problem, policy, and political streams. Each is conceptualized as largely separate from the others, with its own dynamics and rules [20]. The problem stream leads to the question as to why policymakers pay attention to certain problems and not to others. The answer lies in the way officials learn about conditions and the way these conditions become defined as problems. The policy stream includes a wide variety of ideas floating around in the 'policy primeval soup' [20]. Ideas are generated by specialists in political communities and are tried out in various ways. Although there are a huge number of policy ideas, only a few ever receive serious consideration. The political stream consists of three elements: the national (or local) mood, pressure group campaigns, and administrative or legislative turnover [20]. Administrative turnover including the key personnel in government often influences the political agenda in quite dramatic ways.
An important feature of the MS model is the coupling of two or all of the streams that open policy windows. A policy window is a temporal stimulus for choice. When windows open, policy entrepreneurs must immediately seize the opportunity to initiate actions, because policy windows sometimes close very quickly. Kingdon mentioned two types of windows: those that open in the problem stream and those that open in the political stream. According to Zahariadis [20], a problem window triggers the search for a solution to a problem that has already been acknowledged. The process begins with a search for appropriate solutions. On the other hand, a political window begins with the search for a problem for an existing solution.

Lober [18] modified the MS model by adding the collaborative window to the MS model. His model was adjusted to help analyze the collaboration of actors from different sectors in solving environmental issues. He formulated five propositions which enable opening of the collaborative window: (1) the formation of environmental collaboration requires a heightened awareness of a problem, based on scientific research and/or public opinion; (2) the environmental solutions that voluntary environmental collaboration seek are an extension of, rather than, a dramatic departure from those that already occur or are likely to occur in the regulatory arena; (3) there is a correlation between the formation of voluntary environmental collaborations and organizational 'greening' - the willingness of corporations to include environmental considerations in their goals and management process; (4) strong public support for the environment is necessary to encourage consumeroriented companies to participate in specific environmental collaboration; and (5) a collaborative entrepreneur is a critical catalyst in the formation of collaboration. The appearance as well as existence of collaborative entrepreneurs is crucial in analyzing when collaboration happens on a voluntary basis.

Political innovation needs leaders who invest their time and power in drawing the attention of policymakers as well as of citizens to the innovation. An innovative idea is sometimes generated by the innovators and sometimes transferred from external best practices. In the case analyzed in this article, the grassroots action successfully imported the FIT that had succeeded in Europe. The diffusion of innovation theory developed by Rogers [19] analyzes why new technologies and ideas were adopted in a certain context at a certain time. Rogers states that an innovation is a 'social process, even more than a technical matter' [19]. The success of the diffusion of proper ideas and technologies relies on the existence of innovators tackling these problems; Rogers called them 'change agents'. A change agent is 
defined as 'an individual who influences clients' innovation-decisions in a direction deemed desirable by a change agency' [19]. This model is, therefore, useful in explaining the diffusion process of ideas in a political arena by highlighting those who enabled it.

Rogers identified seven roles played by change agents in the process of introducing an invocation in a client system: to develop a need for change, to establish an information exchange relationship, to diagnose problems, to create an intent for change in the client, to translate an intent to action, to stabilize adoption and prevent discontinuance, and to achieve a terminal relationship. To sum up, it is essential for the successful adoption of a certain idea that change agents understand local needs unrecognized by local clients and raise awareness through the introduction of a solution. Through an analysis of specific cases, Rogers derived factors that affect the change agent's success; these are the change agent's effort, client orientation, compatibility with client's needs, and change agent's empathy. The degree of effort from change agents in contacting clients is positively related to the adoption of the innovation by clients. The degree to which innovation is diffused is positively related to client orientation, rather than to a change agency orientation. Another crucial point is that the more compatible the proposed programs are with a client's needs, the more successful the diffusion of innovation.

The case study analysis in this article investigates when the collaboration was initiated and who organized it. This article attempts to combine the perspective of the diffusion of innovation theory with Lober's MS model in order to understand the velocity of the implementation of the FIT in Ontario. By doing this, it discusses which factors enable external actors like grassroots actors to influence policymakers' decision in the grassroots action's direction.

\section{Results and discussion}

\section{The Ontario energy structure: a historical perspective}

In Canada, each province has the exclusive power to make laws in relation to the 'development, conservation, and management of sites and facilities in the province for the generation and production of electricity' (Section 92A, The Constitution Act 1867, the country's founding constitutional document [21]). The federal government is mainly responsible for international treaties, the coordination of transborder problems and knowledge transfer between provinces. All other responsibilities fall under the competency of provincial governments; therefore, provincial policies on electricity market regulation differ fundamentally between provinces. In Quebec, the market is fully controlled by the province, whereas it is partly deregulated in Ontario and fully deregulated in Alberta [22].

While the Ontario Energy Board was the main regulatory body overseeing the industry [1], Ontario's electricity market has long been dominated by Ontario Hydro, a public company which was established in 1906 and known at that time as the Hydro Electric Power Commission of Ontario [23].

Until the 1970s, the planning of Ontario's power system was generally a matter for negotiation within the electricity industry, between Ontario Hydro and the municipal electric utilities, and between the industry and the Ontario government. The task of the industry was to expand the energy supply capacity to meet the increasing demand resulting from economic growth [23]. Since the 1980s, Ontario's electricity market has been controlled by Ontario Hydro's 'Energy Supply/ Demand Plan'.

Although the Energy Supply/Demand Plan had been successful until the early 1990s, the following economic downturn which began shortly after the completion of the Darlington nuclear station made Ontario Hydro's high debt servicing costs and reduced revenue a major public issue. Ontario Hydro finally agreed in its 'Hydro 21 ' report that Ontario's electricity market should be restructured and liberalized.

\section{A political stream opens the policy window: the change of government in 1995}

As some scholars state $[1,2,24]$, the starting point for the changes to Ontario's legislature occurred in the mid1990s when the public energy issue was focused on making the electricity market more competitive. Ontario Hydro argued in Hydro 21 that the electricity system in Ontario should be restructured to follow a more market-oriented model due to the state's serious financial deficit [25].

At the same time, Mike Harris and the then opposition Progressive Conservative Party needed a new approach to Ontario's electricity market to attract voters in the 1995 election, so they pledged in their manifesto to open up the market [13]. In their campaign manifesto entitled the 'Common Sense Revolution,' REs, however, did not receive any attention. Instead the document identified two key policy directions: first, electricity rates were to be frozen for 5 years; and second, the promise was made to consider 'some moves towards privatization of non-nuclear assets' [26].

In September 1995, the Progressive Conservative Party won a majority of seats in the Ontario legislature, defeating the former ruling New Democratic Party [4]. After the 1995 election, the new government appointed a member of the Progressive Conservative Party, Donald 
S. Macdonald, who was also the former Federal Minister of Finance as chair of the Advisory Committee on Competition in Ontario's Electricity System (the so-called Macdonald Committee) [23]. In its 1996 report 'A Framework for Competition', the Macdonald Committee recommended the elimination of Ontario Hydro's monopoly on electricity generation and the introduction of a competitive market [15]. Only in its summary did the report argue that it believed that 'the process of restructuring Ontario's electricity system must be accompanied by... and the introduction of renewable technologies,' while it specifically recommended the enhancement of other fossil fuel energy sources [27]. The 'Direction for Change' issued by the Ontario government in 1997 [13] also illustrates the limited attention that $\mathrm{RE}$ received. In this document, $\mathrm{RE}$ was mentioned only once in a reference to 'cleaner fuels', while the increased efficiency of fossil fuels was explicitly stressed.

The Macdonald Committee effectively paved the way for the electricity market to move away from the Energy Supply/Demand Plan. The Energy Competition and Electricity Acts of 1998 signaled a full-scale shift towards competitive retail and wholesale electricity markets, including the breakup of Ontario Hydro into a number of successor companies [2]. Ontario Power Generation and Hydro One were founded in 1998, and presently, there are approximately 80 distributors [1]. However, the electricity portfolio continued to almost exclusively dominate Ontario's electricity policy [26], and there were delays in opening the electricity market during the late 1990s [28]. The Ontario government acknowledged the need for a more competitive electricity market.

The new ruling party, the Progressive Conservative Party, outlined the restructuring of the electricity market as one of the central policy issues to be tackled by the new government. The Progressive Conservative Party is a right-of-center party whose policy style tends toward liberalism. It decided to open the electricity market to make it more competitive. However, RE did not receive sufficient recognition in the party's new policy.

In May 2000, the Ministry of Energy, Science and Technology announced on its website that the move to a competitive market will create more options for encouraging cleaner, more environmentally friendly green technologies, energy conservation and green power. ... As the competitive market develops, we expect that some customers will demonstrate their preferences to buy environmentally sustainable energy, which creates opportunities for the RE sector' [28]. In April 2002 the Ontario government enacted the Electricity Pricing, Conservation and Supply Act in order to make the electricity market more competitive and to open up the retail market on a voluntary basis. After the opening up of the electricity market on 1 May 2002, members of the government cited the construction of wind turbines in Toronto and Bruce County as evidence of their policy's success [29].

The change of government opened the policy window for the more competitive electricity market to move towards the political window into the problem stream. Ontario decided to make its electricity market more competitive. The FIT requires the opening up of the electricity market. However, this did not change the policymakers' lack of concern about RE. The Darlington nuclear power plant came into operation in the mid1990s, and the government did not privatize the assets of nuclear power plants. This resulted in an only partial opening up of the electricity market which continued to be dominated by the public sector. On the other hand, the FIT was not an attractive alternative for the policymakers at that time as only a few countries had implemented the FIT, and these attempts were still in the experimental stage.

\section{Problem stream: air pollution caused by the coal-fired power plants}

In the late 1990s, the problem of air pollution became a new aspect in the discussion about the future perspective of the energy sector. This was related to the fact that Ontario's coal-fired power plants led to a drastic deterioration in the province's air quality leading to illhealth and death amongst Ontario's citizens. In 1998, the Ontario Medical Alliance (OMA), in cooperation with the Ontario Clean Air Alliance (OCAA), issued a 'Ground Level Ozone Position Paper' to kick off the policy discussion about the decreasing air quality [30]. In the position paper, the OMA delivered a clear message: air pollution was a 'serious health risk,' and the 'primary source' of the problem was the electricity sector in the province, particularly the coal-fired power plants [30]. It also declared in its report of 2000 that air pollution 'will cost Ontario's health care system and economy more than one billion Canadian dollars and result in approximately 1,900 deaths this year' [31]. The media took up this issue and dramatic headlines appeared in Ontario newspapers [4]. This movement caused public anger towards the province's coal-fired power plants.

The OCAA was formed in anticipation of the introduction of competition within the electricity market and, uniquely, by the concern that this could lead to a reduced use of electricity from coal-fired power plants across Ontario. The OCAA was the first organization that connected the electricity market issue to the health care problems caused by the poor air quality [31]. This new issue that arose in the electricity sector became part of the policy landscape through a combination of 
conscious strategic action and uncontrollable circumstances [31]. The OCAA spread its message throughout the province, and, in the result of the polls in 1999 and 2001, the majority of southern Ontario survey respondents wanted coal-fired power plants to be phased out.

In June 2001, the Ontario government established a 'Select Committee on Alternative Fuel Sources' (SCAFS). The SCAFS announced that Ontario would shut down all coal-fired plants by 2015. The SCAFS recommended that a RPS be put in place by 30 June 2003 and stated that it would be one of the toughest standards implemented in North America.

On 9 September 2002, the Liberal Party, the then opposition party, outlined in its manifesto that if it came to power it would close all of Ontario's coal-fired power plants by 2007 [32]. After winning the 2003 election, McGuinty's Liberal government closed the Lakeview Generating Station in Mississauga which represented 1,140 MW of generating capacity. Despite difficulties with electricity supply in Ontario, a new provincial agency, the Ontario Power Authority (OPA), was instructed to 'plan for coal-fired generation in Ontario to be replaced by cleaner sources in the earliest practical time frame that ensures adequate generating capacity and electric system reliability in Ontario' [33]. Afterwards, the OPA published revised plans to complete the coal phaseout in the period between 2011 and 2014 [34]. In fall 2003, the Liberal government announced its new plan to implement the RPS; this plan was the biggest single commitment to RE made by any jurisdiction in North America. The Liberal Party proposed an RPS requirement that $5 \%$ of all generating capacity would be from RE by 2007 ; and $10 \%$, by 2020 [35].

However, the Ontario government did not act quickly enough in its support of RE. The Electricity Conservation and Supply Taskforce stated that the government should move quickly to implement the RPS if it planned to achieve its stated goal of increasing the rate of RE supply in Ontario. The Ministry of Energy issued a 'Request for Proposal' for $300 \mathrm{MW}$ of RE. Ninety private RE developers submitted expressions of interest totaling 4,400 MW [36]. The OPA, tasked with capacity planning, assessed these projects, and in November, the go-ahead was given for ten projects totaling $388 \mathrm{MW}$, of which $355 \mathrm{MW}$ was from wind power.

In spite of the Liberal Party's efforts since coming to power in 2003, RE producers were dissatisfied with the RPS. They complained that some political barriers strongly hindered the implementation of RE projects and made investment in the RE market difficult. Some argued that the Ontario government did not want to invest in RE but in nuclear power plants.

\section{Renewable energy standard offer program}

The RPS was backward in terms of its approach to market liberalization. The combination of the RPS and the competitive market did not work well. In response to the recommendation for stronger market liberalization, the new Liberal government announced further efforts. The RPS did not fit the Liberal Party's strategy for the electricity market. In 2004, the Liberal government commissioned a report on FIT, and in May 2005, the finished report recommended further development of RE [37]. In response to this report, the Ministry of Energy stated that it would initiate a new program, to be called the 'Renewable Energy Standard Offer Program.' In March 2006, the Ontario Premier, Dalton McGuinty, announced that dependence upon the RPS was being supplemented by a commitment to the RESOP [4]. The Liberal government's efforts to promote cleaner energy in the first period did not satisfy the voters, because the phaseout of coal-fired power plants had been postponed several times. The Liberal government decided to implement a market mechanism to promote RE in order to win the next election. The Liberal government had considered the FIT; however, they chose instead the RESOP, which is a FIT-like system for small power generation facilities. The RESOP's requirements were as follows: (1) the guaranteed payback period would be 20 years, (2) the base payment would be $11 \mathrm{c} / \mathrm{kWh}$ for wind, water, and biomass, and $42 \mathrm{c} / \mathrm{kWh}$ for PV, and (3) the project must not exceed $10 \mathrm{MW}$.

Due to its limitations on the available capacity, some NGOs stated that the disadvantages of the RESOP were that potential RE producers were unable to access the grid in certain areas of Ontario and that communities were having difficulty obtaining financing to investigate the feasibility of renewable resource projects in their area [14]. In fact, contracts made under the RESOP detailed projects which were to generate a total of $1,466,388 \mathrm{MW}$, but as of September 2008, only $55 \mathrm{MW}$ of RE was actually generated, far less than the target of 1,350 MW set for the end of 2007. The RESOP was therefore unsuccessful in promoting RE.

Although the Ontario government recognized that RE was necessary, its approaches in promoting RE were unsatisfactory. According to Harper [3], despite the development of RE, it had still not received sufficient political attention. Harper investigated articles in local newspapers in Ontario between 2003 and 2007, regarding how often and in which contexts 'renewable energy' and 'sustainable development' had been used. His results showed that sustainable energy had not been a political issue, and therefore, it had not been placed on the political agenda.

In the early 2000 s, air pollution was acknowledged by citizens and policymakers as a serious health problem 
via a media campaign. Policymakers decided to phase out coal-fired power plants which then entered the problem stream. The phaseout of coal-fired power plants had triggered discussion about RE, and therefore, RE received increased political attention at that time firstly from citizens and thereafter from policymakers. However, RE was still not a strong political issue, and it could not change the atmosphere in the policy arena in support of the idea that RE could fundamentally improve energy issues.

Ontario's strong dependence on an energy portfolio system and the delay in the opening of the electricity market, however, obstructed the FIT being acknowledged as a solution. As a result, the RPS and the RESOP in the policy stream were coupled with the political stream and the policy window opened for them.

Some NGOs and those who wanted to invest in RE have criticized both the RPS and the RESOP because they led to only a small increase in the amount of RE generating capacity. The government also recognized that the FIT might be a powerful tool, but the FIT could not be coupled with other streams. The FIT, at that time, was gaining popularity in Europe, thanks to Germany's success. However there were no strong actors who could make public awareness about the FIT sufficiently high enough for it to be acknowledged in Ontario.

\section{The policy stream: the appearance of a change agent} In the summer of 2008, the Environmental Defense Canada, the Ontario Sustainable Energy Association (OSEA), and 313 other organizations [38], including businesses and political organizations, established the Green Energy Act Alliance (GEAA) and launched a campaign calling for legislation modeled on German laws that would make Ontario a green leader in North America [39]. The mission of the GEAA was to 'reinforce the commitment to conservation and renewable energy... to take advantage of the clean slate that is Ontario's electricity system, which requires an estimated $\$ 60$ billion to reinforce and bring on new generation' [38]. The GEAA was the main actor in the grassroots action that supported the implementation of the GEA and the FIT.

While some NGOs, like the Community Power Fund and the OSEA, had attempted to tackle renewable energy issues for a long time and had had relatively little success, the success of the GEAA was remarkably fast. First, the GEAA launched several media campaigns. The aim of the GEAA was a developmental replacement of the RESOP with the GEA in order to introduce the comprehensive FIT. The GEAA aimed to copy the FIT that had succeeded in Europe, and it drew attention to Germany's success in strengthening the RE industry and lowering its implementation costs. The campaign included educational and lobbying programs and placed emphasis on the economic perspective of the FIT. Working closely with the GEAA members, the OSEA played a major role in this campaign taking it on the road to communities throughout Ontario to educate people about the need for the legislation and encouraging voters to put pressure on their elected representatives to support the GEA [39]. The vision of the campaign was to make Ontario a global leader in renewable energy supply and conservation, creating thousands jobs, economic prosperity, energy security, and climate protection. The OSEA therefore combined both economic and climate change issues related to RE.

The timing was also good for pushing the GEA. The campaign set a deadline for the introduction of the GEA before the 15th Conference of the Parties (COP 15) of the IPCC in Copenhagen in 2009. The COP 15 was especially important for global climate protection because the post-Kyoto framework was due to be decided during this conference. Canada had already stated that it would not achieve its GHG emission reduction targets. Therefore, stronger attention was paid to this conference than had been before.

The Environmental Defense Canada emphasized the economic merit of the FIT throughout the campaign and received positive responses from farmers working in Ontario. By conducting long-term programs with local communities in Ontario to protect nature conservation areas including farmland, the body helped to gain trust of farmers, who were potential investors in RE.

However, one of the most successful actions conducted by the GEAA was the organization of a study tour to Germany, Spain, and Denmark to observe the results of the FIT there by interviewing people from those regions. The GEAA thought it would be helpful to win the support of the then Minister of Energy and Infrastructure, George Smitherman, as he was an influential actor in the Ontario legislature. Smitherman was a member of the Liberal Party, the ruling party in Ontario legislature at that time. He was also the Minister of Health and Long-Term Care between 2003 and 2008 and has been the Minister of Energy and Infrastructure since 2008. To gain Smitherman's approval for the GEA, the GEAA set up the European study tour which Smitherman and other politicians participated in. The GEAA explained to him that the GEA would be a mix of the FIT adopted in Germany, Spain, and Denmark but would most closely mirror the German FIT model. Smitherman visited all three countries in August 2008. After the study tour, he became a strong supporter of the FIT. In contrast to the RPS, the FIT did require a competitive market, and this suited the Liberal Party's strategy for a more competitive electricity market 
and less-expensive policy implementation. Smitherman gave a presentation to the Canadian Club in Ontario on 31 October 2008 about the GEA [40]. In his presentation, Smitherman explained his findings from the study tour in Europe and especially those related to his study of the FITs in Germany and Spain. He acknowledged that the FIT provides an incentive structure that uses government policies and legislative tools to encourage national and regional utilities to adopt RE and is able to create a market for green energy and green jobs. He emphasized that 'the most important lesson is that through strong leadership... and with a strong vision... Ontario can achieve multiple aims' [40]. Cleaner air does not necessarily come at the expense of economic activity, as some would suspect, rather, that economic growth and environmental improvement can go hand in hand. Smitherman emphasized the fact that Ontario had an enviable starting point as during the previous year, $75 \%$ of all the electricity Ontario used was from emission-free nuclear and large hydro plants. Ontario also had the potential to replace fossil fuels with RE through well-received programs such as the RESOP and the Response for the Proposals of the FIT. The Liberal government's forthcoming policies should enhance certainty for investors and will streamline processes of the RE development, which the Liberal Party called the greatest public policy challenge in history. With smart planning to strategically increase investment in infrastructure and in clean, green energy projects, Smitherman found that the FIT could stimulate Ontario's economy, which had suffered since the global economic downturn in 2008. Smitherman emphasized three points in answering the question as to why the Ontario government required the FIT: (1) to close coal-fired power plants, (2) to enhance RE, and (3) to meet this challenge collectively.

With regard to the FIT, the GEAA obtained the approval of the most influential policymaker in the Ontario legislature. Smitherman also said that the environmentalist Dr. David Suzuki was the first person who had suggested to him that he should see the green energy efforts of world-leading jurisdictions for himself. This human connection accelerated discussions about the GEA. The change in the minister's opinion therefore can be seen as the key factor in the GEA's success. The GEAA influenced this key factor through the organization of the study tour to Europe that allowed policymakers to observe the economic success of dynamic renewable energy support systems. The Ontario government saw the GEA after the trip as an economic booster, job creator, and non-air-polluting electricity producer.

The first GEA debate took place on 23 February 2009 in the Legislative Assembly of Ontario. Smitherman explained the economic advantages of the GEA, which he had seen during his time in Germany, Spain, and Italy. He emphasized that if the FIT were implemented, it would create 50,000 new job opportunities in Ontario's energy sector. The GEA would change 15 related laws and would, therefore, have a strong impact on Ontario's legislation.

Interestingly, the GEAA included only one speech in the Legislative Assembly of Ontario about the GEA. However, other NGOs and politicians have often cited and shown support for the GEAA. Some of these commentators were also members of the GEAA, though others were not, such as the World Wildlife Fund. The vote was held on 14 May 2009. The GEA passed with 59 ayes and 13 nays. The GEA was implemented only 10 months after the establishment of the GEAA and Smitherman's visit to Germany.

Lober suggests that we should also consider the collaborative window in which an environmental policy measure is realized by diverse actors working together. Although the FIT existed in all three streams: the problem, policy, and political streams, the policy window did not open for the FIT. The FIT, in Ontario's case, needed the collaboration of diverse actors, which occurred in 2008 through the establishment of the GEAA. Lober stated that as a result of the collaborative window opening, policy change accidentally happens. However, public awareness about the FIT and public support for it were unlikely to be influential enough. In the case of Ontario, we have to ask ourselves why the collaborative window opened despite a lack of public awareness.

The answer lies in the strategy the GEAA adopted. The GEAA took on the role of a change agent. The GEAA, in its grassroots action, supplemented the lack of public awareness by acquiring the support of an important policymaker. The GEAA took Smitherman to Europe to show him that implementation of the FIT would result in both economic as well as environmental success. It was particularly important that the GEAA placed emphasis on economic factors throughout the campaign. The GEAA led a campaign, oriented on the client's needs for the search for a solution both to Ontario's economic and environmental challenges.

Lober's propositions were not completely fulfilled in the case of Ontario in terms of a lack of public awareness and support for RE. Therefore, the GEAA targeted policymakers in order to gain political attention in the legislature. The GEAA reinforced the lacking public awareness by increasing the policymakers' approval and opened the collaborative window for the FIT.

The FIT was not a completely new idea, having actually been present in the policy stream since 2004. However, it could not be combined with other streams because it had not received sufficient public attention. 
The GEAA started its campaign in 2008 to introduce the FIT, a model that had led to the successful development of RE in Europe and had therefore gained the attention of the policymakers, supplementing the lack of public awareness. This resulted in the coupling of the streams in Ontario and the opening of the policy window for the FIT.

\section{Conclusion}

The Green Energy Act Alliance rapidly succeeded in putting the FIT on the policy agenda in Ontario. This article analyzed this process, taking into account the MS model. Lober's collaborative window model suggests that a change in environmental policy sometimes requires the collaboration of various actors and that five propositions need to be fulfilled to open the collaborative window. In Ontario's case, however, one of the propositions, the existence of high public awareness, was not present. This article explains this by applying the diffusion of innovation theory. The diffusion of innovation theory allows us to draw the conclusion that the lack of public awareness could be compensated by the political campaign which was organized by the GEAA to raise the policymakers' attention. This led to successful collaboration between the grassroots actors and the legislature. This article therefore concludes that the GEAA's activities opened the collaborative window and substantially contributed towards the implementation of the FIT.

The Ontario case contrasts greatly to the policy process involved in the German FIT (for example, Bechberger and Reiche [41], and Jacobsson and Lauber [42]). The German FIT which was enacted in 2000 had been stimulated by the strong civil engagement which began in the 1970s. After a long discussion in society about energy policy, some successful cases of a FIT-like system have, since 1990s, been evident at a regional level. In addition, the industries which have profited by RE have also shown strong support to the FIT in the German policy arena, whereas economic organizations, for example the Federation of German Industry, opposed the FIT. The Social Democratic/Green Coalition which came to power in 1998 was aware of all of these movements, and the Renewable Energy Act implementing the FIT was passed in 2000.

In Ontario, the energy issue became a problem at the beginning of 2000s, and this was connected to environmental and health issues in the discussion about the phasing out of coal-fired power plants. The delay in the phaseout led to a debate about RE. The failure of the Renewable Portfolio Standards led to discussions regarding the implementation of market mechanisms for RE, and as a result, RESOP was implemented. As the
RESOP received strong criticism from NGOs and RE producers, the government needed to provide an alternative to the RESOP. In fact, the FIT had already been discussed before the foundation of the GEAA in summer of 2008. The policy window opened in Ontario despite the fact that it is not satisfying Lober's propositions. Public awareness was not high, compared to the German case in which the public had long supported RE

This article explains this in relation to the efforts of a change agent. Grassroots action, in order to implement a desired policy measure, does not need to make the public acknowledge the problem, but it must convince policymakers to support the policy measure. Of course, the fact that the GEAA talked with members of the public and that the Environmental Defense Canada gained the support of local farmers who were potential investors in RE should not be ignored. However, the support of Smitherman, the then Minister of Energy and Infrastructure, had a major influence on the policymaking process in Ontario. The GEAA, by emphasizing the economic merits of the FIT, made Smitherman change his opinion in support of the harmonization of a more competitive electricity market and the reduction of air pollution caused by coal-fired power plants.

The collaborative window model can still explain a great deal about policymaking on environmental issues. This article offers an explanation for cases in which not all Lober's propositions are fulfilled. If grassroots action, in which different actors collaborate together, takes an adequate strategy to communicate with influential policymakers, led by the policymakers' interests, then it seems possible that the collaborative window may be opened despite the lack of public awareness.

This article does not consider the significance of veto players, who ignore or oppose innovation. In the Ontarian FIT case, there was surprisingly little protest during the discussion. Politicians, plus automobile and cement industries, were the main dissenters, who stressed the disadvantages of the FIT as it increased the electricity price to an unacceptable level. Scholars agree that this opposition was very limited in the case analyzed in this article. The question arises therefore as to what would happen if grassroots action encounters strong protest from influential veto players, and this could offer an interesting future topic for discussion.

\footnotetext{
Abbreviations

FIT: feed-in tariff; GEA: Green Energy Act; GEAA: Green Energy Act Alliance; GHG: greenhouse gases; MS: multiple stream; OCAA: Ontario Clean Air Alliance; OMA: Ontario Medical Alliance; OPA: Ontario Power Authority; OSEA: Ontario Sustainable Energy Association; PV: photovoltaic; RE: renewable energy; RESOP: Renewable Energy Standard Offer Program; RPS: Renewable Portfolio Standards; SCAFS: Select Committee on Alternative Fuel Sources.
} 


\section{Authors' contributions}

KN solely analyzed existing studies and provided this article. KN read and approved the final manuscript.

\section{Competing interests}

The author declares that they have no competing interests.

Received: 16 September 2011 Accepted: 20 March 2012

Published: 20 March 2012

\section{References}

1. Yatchew A, Baziliauskas A (2011) Ontario feed-in-tariff programs. Energy Policy 39(7):3885-3893. doi:10.1016/j.enpol.2011.01.033.

2. Winfield M, Gibson RB, Markvart T, Gaudreau K, Taylor J (2010) Implications of sustainability assessment for electricity system design: the case of the Ontario Power Authority's integrated power system plan. Energy Policy 38:4115-4126. doi:10.1016/j.enpol.2010.03.038.

3. Harper M (2010) Sustainable and renewable energy development in Ontario: a look at the current policy frameworks and discourses surrounding sustainable energy and wind and solar power in major Ontario newspapers. McMaster J Commun 5:43-68

4. Rowlands IH (2006) The Development of Renewable Electricity Policy in the Province of Ontario. Rev Pol Res 24:185-207

5. Mendonça M (2007) Feed-in tariffs: accelerating the deployment of renewable energy. Earthscan, London

6. REN21 (2010) Renewables 2010 Global Status Report, Paris.

7. Statistics Canada (2011) Gross domestic product, expenditure-based, by province and territory. http://www.statcan.gc.ca/tables-tableaux/sum-som/ 101/cst01/econ15-eng.htm. Accessed 20 Aug 2011

8. Government of Ontario (2011) Economy - overview. http://www.ontario.ca/ en/about_ontario/EC001036.html. Accessed 20 Aug 2011

9. IESO (2011) Demand overview. http://www.ieso.ca/imoweb/media/ md_demand.asp. Accessed 20 Aug 2011

10. IESO (2011) Supply overview. http://www.ieso.ca/imoweb/media/ md supply.asp. Accessed 20 Aug 2011

11. Environment Canada (2011) National inventory report 1990-2009: executive summary. http://www.ec.gc.ca/ges-ghg/defaultasp?lang=En\&n=72E6D4E2-1. Accessed 20 Aug 2011

12. Ontario Ministry of Environment (2010) Climate change action plan annual report 2008-09.

13. Green Energy Act Alliance (2009) Green Energy Act Alliance. http://www. greenenergyact.ca/. Accessed 20 Aug 2011

14. Ontario Power Authority (2011) FIT Program. http://fit.powerauthority.on.ca/ what-feed-tariff-program. Accessed 20 Aug 2011

15. Government of Ontario (1997) Direction for change: charting a course for competitive electricity and jobs in Ontario. Ministry of Energy, Science and Technology, Ontario

16. Kingdon JW, Thurber JA (2003) Agendas, alternatives, and public policies. Longman, New York

17. Cohen MD, March JG, Olsen JP (1972) A garbage can model of organizational choice. Adm Sci Q 17(1):1-25. doi:10.2307/2392088.

18. Lober DJ (1997) Explaining the formation of business-environmentalist collaborations: collaborative windows and the Paper Task Force. Pol Sci 30:1-24. doi:10.1023/A:1004201611394.

19. Rogers EM (2003) Diffusion of innovations. Free Press, New York, 5

20. Zahariadis N (1999) Ambiguity, time, and multiple streams. In: Sabatier PA (ed) Theories of the policy process. Westview Press, Boulder pp 73-93

21. Government of Canada (2006) Constitution Acts 1867 to 1982. http://laws. justice.gc.ca/eng/Const/Const_index.html. Accessed 20 Aug 2011

22. Simpson J, Jaccard M, Rivers N (2007) Hot air: meeting Canada's climate change challenge. McClelland \& Stewart, Toronto

23. Ontario Power Authority (OPA) (2005) Supply mix advice report, Ontario

24. Ontario Power Authority (OPA) (2010) Feed-in tariff program - program overview.

25. Trebilcock MJ, Hrab R (2005) Electricity restructuring in Ontario. Energy J 26:123-146

26. Progressive Party of Ontario (1994) The common sense revolution, Ontario.

27. Advisory Committee on Competition in Ontario's Electricity System (1996) A framework for competition, Ontario.

28. Government of Ontario (2000) About the Ministry, frequently asked questions, electricity restructuring and Bill 35, the Energy Competition Act,
1988. http://www.est.gov.on.ca/English/am/am_faq.htm. Accessed 20 Aug 2011

29. Dunlop G (2002) Remarks by the member for Simcoe North. Legislative Assembly of Ontario, Ontario

30. Ontario Medical Association (1998) OMA ground level ozone position paper, Ontario.

31. Ontario Medical Association (2000) The illness costs of air pollution in Ontario: a summary of finding, Ontario.

32. Moore P (2003) Ontario votes 2003 - party platforms: environment. CBC News

33. Ontario Ministry of Energy and Infrastructure (2006) Directives to OPA Ontario

34. Ontario Power Authority (OPA) (2007) Ontario's Integrated Power System Plan: the roadmap for Ontario's electricity future (preliminary), Ontario.

35. Bradely D (2005) Renewable Portfolio Standard (RPS) \& other incentivesharmonization opportunities in Canada, Ottawa.

36. Toronto Star (2007) Ontario seeks to double contracted supply of "green" power; Renewable energy developers cite policy barriers. Toronto Star (in press)

37. Smith C (2005) Renewables in Ontario's energy future. Toronto Star

38. Green Energy Act Alliance (2009) About us http://www.greenenergyact.ca/ Page.asp?PagelD=122\&Content $\mid \mathrm{D}=910 \&$ SiteNodelD=203\&BL_Expa Accessed 20 Aug 2011

39. Ontario Sustainable Energy Alliance (2010) The Green Energy Act. http:// www.ontario-sea.org/Page.asp?PagelD=924\&Content|D=1141. Accessed 20 Aug 2011

40. Green Energy Act Alliance (2008) Green energy in the news: remarks by the Honorable George Smitherman, Minister of Energy, Canadian Club. http:// www.greenenergyact.ca/Page.asp?

PagelD=122\&Content $\mid \mathrm{D}=947 \&$ SiteNodelD=214. Accessed 20 Aug 2011

41. Bechberger M, Reicher D (2004) Renewable energy policy in Germany: pioneering and exemplary regulations. Energy Sustain Dev 8(1):47-57. doi:10.1016/50973-0826(08)60390-7.

42. Jacobsson S, Lauber $V(2004)$ The politics and policy of energy system transformation-explaining the German diffusion of renewable energy technology. Energy Policy 34:256-276

doi:10.1186/2192-0567-2-6

Cite this article as: Nishimura: Grassroots action for renewable energy: how did Ontario succeed in the implementation of a feed-in tariff system? Energy, Sustainability and Society 2012 2:6.

\section{Submit your manuscript to a SpringerOpen ${ }^{\circ}$ journal and benefit from:}

- Convenient online submission

- Rigorous peer review

- Immediate publication on acceptance

- Open access: articles freely available online

- High visibility within the field

- Retaining the copyright to your article

Submit your next manuscript at $\gg$ springeropen.com 